\title{
OD 11. SEPTEMBRA K PANDÉMII: 20 ROKOV FILOZOFIE GLOBÁLNYCH KONFLIKTOV
}

\section{Rozhovor s Marekom Hrubcom}

V situácii vyhrotených globálnych konfliktov vzniká naliehavá potreba analytického a syntetického kritického myslenia. Akademickú platformu na diskusiu už dvadsat rokov poskytuje slovensko-česká každoročná novembrová konferencia Filosofie a sociální vědy, ktorej spoluorganizátorom je aj Filozofický ústav Slovenskej akadémie vied. Hlavným iniciátorom a zakladatel'om je docent Marek Hrubec, filozof a sociálny vedec, riaditel' Centra globálnych štúdií Filozofického ústavu Akadémie vied Českej republiky v Prahe, člen Európskej akadémie vied a umení a koordinátor výskumného programu o globálnych konfliktoch a lokálnych súvislostiach. S kolegami z Chicaga založil svetovú siet' globálnych štúdií a bol prvým rektorom univerzity na hraniciach Burundi, Rwandy a Konga pre študentov z konfliktných a postkonfliktných afrických krajín. Teraz zameriava svoju pozornost' najmä na výskum vzt'ahov medzi hlavnými svetovými mocnost’ami EÚ, USA a Čínou v Č́nskej akadémii sociálnych vied a pracuje na etablovaní nového centra globálnych štúdií na univerzite v nigérijskom hlavnom meste Abudži. Popri vlastnom výskume o globálnej sociálnej a politickej spravodlivosti takto buduje inštitúcie, kde je možné výskum tejto komplexnej témy medzinárodne tímovo vykonávat'. Publikoval mnoho článkov a je autorom a editorom vyše dvadsiatich kníh z oblasti sociálnej a politickej filozofie a príbuzných sociálnych vied. Prednášal v mnohých európskych krajinách, ale aj v USA, Číne, Indii, Rusku, Palestíne, Iráne, Indonézii, Južnej Kórei, Brazílii, Čile, Uruguaji, Burundi, Rwande, Etiópii, Nigérii, na Kube, Novom Zélande a inde.

Ladislav Hohoš: Za posledných dvadsat' rokov sme boli svedkami rozmanitých globálnych konfliktov, počnúc udalostami 11. septembra 2001 cez dôsledky globálnej ekonomickej krizy (2008), celoplanetárnych klimatických zmien až po aktuálnu pandémiu koronavírusu. Ako sa tieto okolnosti prejavili v programe dvadsiatich ročníkov konferencii?

Marek Hrubec: Je faktem, že když jsme pořádali první konferenci o globálních rozporech dva měsíce po 11. záŕí 2001, měly tyto události značný vliv na její atmosféru. 
Zatímco $\mathrm{v}$ devadesátých letech na povrchu převládal jeden veřejný diskurz, od začátku nového století a tisíciletí dosavadní rozpory doutnající pod povrchem několikrát vyvřely jako výbuchy sopky, at' už to bylo 11 . záŕí, poté globální ekonomická krize, nebo další propady zmíněné v otázce. Už Platón, Aristoteles nebo Konfucius reflektovali podobné dimenze rozporů své tehdejší doby a dokázali je abstraktněji zpracovat ve svých filosofiích. Dnes už ale nežijeme v městských státech jako v antice, ani v relativně suverénních národních státech, ale ve světě planetárně provázaných konfliktů, které vyžadují rekonceptualizaci intersubjektivních vztahů mezi lokálním, národním, regionálním a globálním. Naše každoroční konference Filosofie a sociální vědy usiluje o interdisciplinární kritické rozbory obecně důležitých problémů společnosti, politiky a civilizace. Tyto obecnějš́ analýzy však provádíme v souvislosti s rozbory aktuálních konfliktů a krizí, kterými se ony obecné zásadní problémy manifestují v přítomné chvíli.

Jednotlivé události přitom upozorňují na různé aspekty globálních konfliktů. Zatímco 11. 9. upozornilo především na intercivilizační politické spory, krize 2008 na ekonomické rozpory, klimatické změny na environmentální problémy a současná pandemie na zdravotní rizika. Nicméně každý z těchto problémů pochopitelně zahrnuje komplexněji rovněž ostatní dimenze. Obsahují také další aspekty: bezpečnostní, vojenské a jiné. Například pandemie fakticky nechtěně slouží také jako test potenciální biologické války v planetárním měřítku. Př̌i výčtu globálních konfliktů nelze opomenout také zprostředkované a př́mé vojenské konflikty, nebot' do lokálních válek v Sýrii, Iráku nebo na Ukrajině jsou zapojeny regionální a světové velmoci. To vyžaduje nové filosofické a sociálněvědní pochopení této proměněné dynamiky současné doby. Hegelova idea národního státu ani Kantovo kosmopolitní stanovisko, ale ani další koncepce z devatenáctého a dvacátého století na to už nestačí.

Jubilejná dvadsiata konferencia v Prahe a v Bratislave (teraz online) nesie názov Iluze o spoločenském uspořádaní. Prečo takáto téma práve dnes? Prekonávame ilúzie studenej vojny?

Téma lze chápat jako iluze, které lidé v Česku, na Slovensku a v řadě dalších zemí v posledních desetiletích měli o daném uspořádání společnosti a hlavně o možnostech přechodu $\mathrm{k}$ uspořádání spravedlivějšímu. Tyto iluze často v pozadí implicitně, nebo dokonce explicitně převládají také v sociální a politické filosofii a sociálních vědách a mají už své dlouhé kořeny v dějinách filosofie a vědy, např́íklad v Rousseauově narativu o věku nevinnosti nebo v Lockově dojmu, že v jeho (a tedy v zásadě i v našem současném) uspořádání jsou stále dostupné zdroje pro všechny. 
Některé z těchto iluzí již pomohli identifikovat kolegové, kteří se věnují např́íklad dějinám filosofie či logice. Každý rok na konferenci akcentujeme spolupráci s jinými vědami, vloni také s archeology. Náš výzkum vyžaduje zkoumat také počátky civilizací, v nichž jsou často zakotveny společenské patologie, jež poté v průběhu dějin eskalovaly a hypertrofovaly. To se v našich evropských kulturních souraadnicích dosud spojovalo hlavně s rozbory antického Řecka a počátků technokratických tendencí popisovaných napríklad Homérem. Tuto evropskou civilizaci, interpretovanou po tisíce let především západocentrickým způsobem, však nelze izolovat. Na konferenci jsme vloni spolu s archeology mapovali také počátky městských civilizací v Mezopotámii či rané fáze vývoje slovanských osídlení a snažili se identifikovat míru tehdejší společenské hierarchie, (ne)rovnosti a (ne)spravedlnosti. Teprve na základě rozborů historického vývoje a současného stavu přinejmenším hlavních civilizací a společenských systémů je možné hledat odpověd’ na otázku o patologiích celé dnešní lidské civilizace. Po analýzách těchto počátků a vývoje však byla většina pozornosti na konferenci věnována iluzím v posledních desetiletích a tomu, jak se reflektují ve filosofii a sociálních vědách, včetně trivializací plánování, trhu, sociálního státu, parlamentních voleb apod. Už nežijeme ve studené válce bipolárního světa mezi USA a SSSR jako do roku 1989, ani v liberálním triumfalismu devadesátých let. Na scéně je nyní více globálních mocností se svými modely uspořádání. Ocitáme se v multipolární, a částečně multilaterální fázi daleko více komplexně strukturovaných společností, jejichž mocenská centra se krystalizují v redefinovaných konfliktních sférách ekonomiky, politiky, společnosti, kultury a technologií.

Konferencie Filosofie a sociální vědy sa zdefinície vyznačujú interdisciplinárnym prístupom, ktorý je potrebný na tieto komplexné analýzy. Ako sa darí spolupráci odborníkov rôznych disciplin a špecializácií?

Zatímco dvacáté století bylo érou specializace a vzniku stále více vědeckých disciplín, subdisciplín a úzkých analýz, vzhledem $\mathrm{k}$ nástupu big data a jejich masovému počítačovému zpracovávání již nejsou úzce specializovaná data a interpretační vědění o mnoha detailech samy o sobě velmi ceněnými statky. Někdy se jimi stanou, ale většinou díky jejich zapojení do širších souvislostí s ekonomickým, vojenským či společenským významem. Dnes se opět začíná vynořovat potřeba syntetických pohledů, které mohou sjednotit relevantní, úzce analytické př́stupy. To je opět př́ležitost pro filosofii, ovšem nikoli ve smyslu izolované spekulace, ale ve spolupráci s řadou věd. V našem výzkumu v Centru globálních studií, včetně jeho prezentací na každoroční konferenci, se pohybujeme především na polích sociální, politické, morální, ekonomické a environmentální filosofie v kooperaci s různými vědami, především se socio- 
logií a politologií $\mathrm{v}$ širším rámci globálních studií. Nicméně spolupracujeme s kolegyněmi a kolegy $\mathrm{z}$ dalších věd, humanitních, společenských a částečně rovněž přírodních.

A túto spoluprácu centrum rozvíja nielen v česko-slovenskom rámci, ale v globálnom celosvetovom rozsahu.

Předně bych rád uvedl, že jsem naši česko-slovenskou konferenci původně začal organizovat každý rok na podzim jako místní či regionální akci paralelní k naší mezinárodní konferenci, kterou každý rok na jaře $\mathrm{v}$ Praze pořádáme $\mathrm{s}$ kritickými teoretiky a dalšími kriticky uvažujícími autory hlavně ze západních zemí. Tuto konferenci začal původně organizovat Jürgen Habermas jako dialog mezi Západem a Východem, nicméně postupně se $\mathrm{v}$ průběhu času $\mathrm{v}$ důsledku pádu východního bloku tematicky zaměřila především na západní témata. Naše místní každoroční konference s českými a slovenskými účastníci navazuje na tuto mezinárodní konferenci svým kritickým př́istupem, ale liší se v tom, že je tematicky zaměřena na globální otázky a jejich lokální interakce.

Naši podzimní místní konferenci se slovenskými a českými účastníky je tedy možné chápat jako dveře do našich různých mezinárodních aktivit. Kromě této místní či regionální konference totiž organizujeme s kolegy v Centru globálních studií v Praze ještě několik dalších každoročních konferencí, zaměřených na hlavní makroregiony světa: jednu již uvedenou mezinárodní konferenci s kolegy ze západních zemí, další s kolegy z Číny, další s kolegy z Ruska, další s kolegy z Afriky a jednu také s kolegy z muslimských zemí. Těchto šest každoročních akcí a několik dalších menších, které dohromady zahrnují přednášky okolo dvou set zahraničních hostů ročně plus desítky místních přednášejících, nám spoluvytvářejí podmínky pro kritický výzkum témat důležitých makroregionů světa $\mathrm{v}$ rámci transnacionálních vědeckých týmů. Přitom ještě v zahraničí spoluorganizuji další akce. Zkoumání dnešních komplexních problémů nutně vyžaduje nejen individuální lokální, ale také týmový mezinárodní výzkum a jeho prezentaci a komunikaci.

Zdá sa, akoby do popredia vystupovala ekologická kriza a globálne klimatické zmeny. Nevystupujú niekedy ekológovia príliš zahl'adení do seba a svojej problematiky?

Každý z nás je specialistou na nějaká témata a subtémata a zároveň se snaží zaujmout širší interdisciplinární záběr. Také ti, kteří se věnují environmentální filosofii a př́ibuzným specializacím, to tak činí, takže někdy převládne jen užší zaměření, jindy zase širší. Naší přidanou hodnotou ovšem je, že neanalyzujeme ekologické otázky izolovaně, nebo jen ve vágním moralistním rámci, jak je to obvyklé. Snažíme se zasadit 
eskalaci ekologické krize do komplexnějš́ího výzkumu vývoje jednotlivých společensko-ekonomicko-politických uspořádání a civilizací a lidské civilizace obecně.

Konflikty záujmov sa tak či onak sústred’ujú vo sfére politiky. Môže hlbšie poznanie globálnych problémov pozitivne ovplyvnit' politické elity, aby hl'adali pozitívne východiská namiesto militarizmu a agresívneho populizmu?

To je patrně nejtěžší otázka. Malá země s pouhými deseti milióny obyvatel jako Česká republika nemá př́liš velkou váhu ve světové politice a spíše se jen přizpůsobuje. Ale není to nic nového, dřive jsme byli závislí na SSSR, předtím na Německu a ještě dřive na Rakousku-Uhersku, nyní více globálně. Regiony a makroregiony světa se k sobě sporně i kooperačně vztahují a s tím je třeba pracovat také v normativních návrzích, které nemají řešení jen v malých místních projektech. To by bylo dočasně možné pouze $\mathrm{v}$ některých verzích makroregionálního nebo globálního kolapsu, s jehož různými scénáři je samozřejmě třeba také počítat.

Je však třeba začínat participativně ze zdola. Výzkum, včetně sociální a politické filosofie, se sice nejčastěji aplikuje v pedagogických aktivitách na univerzitách, ale dalšími vlivnějšími sférami využití poznatků jsou doma i v zahraničí občanská společnost, sociální hnutí, státní a nadstátní správa, diplomacie, agentury OSN apod. Ale praktická sféra většinou zůstává v zajetí starých konceptů, jež vyhovují stávající mocenské konstelaci, a podle toho to také vypadá.

Zdá sa, že stratégie a metódy riešenia ekonomických a politických kríz, ktoré sa osvedčili v minulosti, zlyhávajú. Hladači alternativ to od polovice devätnásteho storočia nemali l'ahké. Vieme načrtnút hl'adanie alternativ spoločenského poriadku namiesto jednostranného presadzovania takzvaného nového svetového poriadku?

Na rozdíl od klasiků z devatenáctého století víme, že historický vývoj není deterministicky určen po jednoduché trajektorii. Je podstatně komplexnější a obsahuje rovněž zvraty a regres, jak víme nejpozději od druhé světové války. Zhroucení tehdejšího neudržitelného řádu a nastolení nacistického autoritářství bylo pro kritické filosofy a vědce zlomem $v$ přehodnocení toho, co jsou různé iluze a jak mají být formulovány budoucí alternativy. Nyní se ocitáme v situaci podobného nebezpečí, ale v jinak strukturovaném prostředí. Někteří si ale žádné poznatky z tehdejší historie neodnesli a stále dnes opakují tehdejší stanoviska několika proudů myšlení s pouze lehkými redefinicemi, které nás vedou k dalším krizím či ještě horším scénářům. Pokud se neuskuteční změna pomocí postupných transformací v nějaký spravedlivější a udržitelnější model, dojde dříve nebo později k rychlé změně při zhroucení globálního kapitalismu. 
Dnes si prítom už nevystačíme s dichotomií transformace versus revoluce, ale $\mathrm{v}$ reálném světě vidíme $\mathrm{v}$ posledním období kontinuum, včetně různých revolučních transformací a transformativních revolucí, jako např́iklad v Číně, Indii, arabském jaru apod., s progresem i regresem. Dále jsem již naznačil, že v globálním prostředí se dnes setkáváme nejen s bipolaritou, ale s kombinací unipolarity, bipolarity a multipolarity. Jednotlivé modely uspořádání přitom představují více variant než za studené války. Je zde především o model ordo-neoliberalismu v hlavní světové velmoci a jeho mírnější varianty takzvaného evropského sociálního modelu, přičemž mnoho dalších zemí bylo v posledních desetiletích dovedeno $\mathrm{k}$ následování různých verzí onoho prvního modelu. Dále existují alternativní modely, zejména model socialismu s čínskými charakteristikami, ruský model, latinskoamerické socialistické experimenty a různé islámské koncepce uspořádání. Tyto modely jsou poměrně schopné zadržovat zahraniční vměšování, ale zatím však měly menší vliv se svojí vlastní realizací v jiných zemích, přestože např́iklad některé africké země čínský model částečně následují, nebot' chtějí podobným způsobem odstraňovat chudobu apod. Odpovědi na otázku, jaké tyto modely přesně jsou, si lze přečíst také v článcích a knihách, které u nás i jinde vydáváme.

Konferencie sú späté s vydávaním monografií a v renomovanej edícii Filosofie a sociální vědy v nakladatel'stve Filosofia vyšlo už asi sedemdesiat knižiek. Pripomeniem ostatné dva tituly Filosofie a ohrožená Země a Autoritářství. Edícia sprostredkúva vybrané tituly súčasných odborníkov z celého sveta, často priekopníkov, ale aj českých a v menšom rozsahu aj slovenských autorov, medzi ktorými sa rozvinula spolupráca v rámci kritického filozofického a sociálneho výskumu. Aké sú najvýznamnejšie výsledky týchto aktivit?

Ediční řada Filosofie a sociální vědy mapuje transdisciplinární výzkum z perspektiv sociální, politické, ekonomické, právní, environmentální a morální filosofie a spolupracujících humanitních a sociálních věd. Snaží se přispívat k rozvoji kriticky orientované teorie prostřednictvím rozborů významných obecných i aktuálních témat $\mathrm{z}$ hlediska různých progresivních interpretací. Čtenáři možná už zaregistrovali známé opusy od Williama Robinsona, Jürgena Habermase, Axela Honnetha či Charlese Taylora, které jsme vydali. Rád bych připomněl několik relevantních titulů $\mathrm{z}$ dalších oblastí světa. Publikovali jsme např́íklad knihu od Wei Xiaoping Ekonomická a politická transformace Č́ny, od Muhammada Ábid al-Džabirího Kritika arabského rozumu nebo od Alberta Kasandy Současná africká sociální a politická filosofie. Nyní chystáme k vydání knihu o koncepci současných ruských zahraničních vztahů. Dohromady tyto tituly nabízejí určité porozumění. $\mathrm{O}$ našich vlastních knihách skromně 
pomlčím, čtenáŕi si je na webové stránce ediční řady př́ípadně najdou sami. Ediční řada je však pochopitelně jen naším domácím zázemím, publikujeme také jinde, doma i ve světě.

Je přitom všem třeba připustit, že samozřejmě nestačíme dobíhat realitu, která utíká, a její vývoj je obtížně korigovatelný. Jak říkají klasici, vše plyne a rychle se mění. Dějiny nás učí, že válkám, krizím a dalším katastrofám se často nevyhneme. Můžeme je ale alespoň spolu s dalšími aktéry kriticky identifikovat a usilovat o jejich omezení, snažit se je podrobněji a komplexně vysvětlit, a přitom formulovat normativní alternativy sociální a politické spravedlnosti.

Zhováral sa: Ladislav Hohoš

Ladislav Hohoš

Vígl’ašská 9

85107 Bratislava

Slovenská republika

e-mail: ladislav.hohos@gmail.com
Marek Hrubec

Centrum globálních studií

Filosofický ústav Akademie věd ČR

Jilská 1

11000 Praha, Česká republika

e-mail: hrubec@flu.cas.cz 